\title{
PEMIKIRAN PENDIDIKAN ISLAM DALAM PERSPEKTIF IBNU SINA
}

\author{
Wely Dozan \& M. Farhan Hariadi*
}

\begin{abstract}
This paper tries to discuss the views of Ibn Sina in Islamic education and its relevance in modern education today. The concept of education according to Ibn Sina aims to develop all the potential possessed by someone towards a perfect direction, namely physical, intellectual and moral development. In addition, the purpose of education must be directed at efforts to prepare someone to be able to live in the community together by doing the work or skills chosen in accordance with their talents, readiness, tendencies and potential. These assumptions caused Ibn Sina to reconstruct and provide a new direction of thinking to develop a better and better quality education. In short, this paper will trace the philosophical meaning in Ibn Sina's thoughts on education through philosophical bases of thought.
\end{abstract}

Keywords: Thought, Education, Ibn Sina

\section{Pendahuluan}

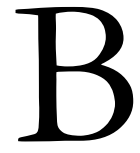

erangkat dari al-Qur'an sebagai ajaran Islam yang bersifat universal yang memiliki berbagai subtansi pembahasan yang termuat di dalam kandungan ayat tersebut. Sehingga alQur'an selalu eksis berbicara dalam berbagai konsep segala bentuk problematika. Kaitanya terhadap pendidikan yang selama ini diartikan sebagai sebuah proses pembelajaran sekaligus sebagai bahan pembelajaran yang diajarkan kepada manusia sebagai basis ilmu pengetahuan (Basri, 2009: 14). Maka al-Qur'an memandang pendidikan sebagai salah satu persoalan pertama dan utama dalam membangun dan memperbaiki berbagai kondisi salah satunya

*Universitas Islam Negeri UIN Sunan Kalijaga Yogyakarta @mail: welydozan77@gmail.com 
termasuk memperbaiki tingkah laku yang diharapkan (Farikhah, 2011: 239).

Hal tersebut menunjukkan bahwa, pendidikan sebagai salah satu aspek yang sangat penting untuk diterapkan dalam kehidupan, karena pada dasarnya pendidikan bukan hanya sebatas mendidik murid, melainkan yang lebih penting adalah mengembangkan potensi yang dimiliki oleh setiap manusia agar apa yang diwujudkan sesuai dengan apa yang di inginkan (Machali, 2012: 145).

Secara spesipik, proses pendidikan perlu didukung dengan membangun lingkungan yang kondusif dalam pengembangan ilmu, serta moralitas dalam memperoleh dan mendayagunakan ilmu tersebut. Semuanya harus dicermati mengingat perkembangan dunia serta perubahan sosial yang cepat, baik yang bersifat positif maupun negative. Perkembangan yang dinamis pada ilmu pengetahuan dan teknologi ini memiliki dampak yang besar ada dunia pendidikan, terutama pada ranah afektif, yakni degradasi moral khususnya di kalangan peserta didik.

Untuk melahirkan pendidikan yang berkualitas, harus berangkat pada metodologi pikir yang kuat dan landasan filosofis epistemologi yang handal. Berdasarkan paradigma humanis-religious harus mempertimbangkan akal sehat, individualism menuju kemandirian, pendidikan pluralis, anti-dikotomi, semangat menggali ilmu yang tulus, fungsionalisme, mengalahkan simbolisme, serta penghargaan dan sanksi. Pendidkan Islam sebagai tujuan, alat perubahan, dan transformasi sosial sudah semestinya diarahkan untuk mengakomodasi budaya lokal dan berorientasi kedapan, yakni yang religious dan modern (Putra, 2015: 192).

Dengan demikian dapat ditarik benang merah bahwa, konsep pendidikan sangat penting untuk diterapkan dalam jehidupan secara terus menerus. Hal tersebut menunjukkan adanya rekontruksi baru dan berbagai model pemikiran untuk mencapai sebuah tujuan pendidikan. Lebih-lebih dalam tulisan ini memfokuskan pemikiran pendiidkan Islam dalam perspektif Ibnu Sina merupakan salah satu tokoh besar dunia Islam yang memiliki pengaruh sangat luas, tidak hanya di dunia Islam, tetapi juga di dunia Barat. Cakupan keahliannya 
pun cukup luas, mulai ke-dokteran, filsafat, hukum Islam, hingga pendidikan. Dengan demikian, merupa-kan kajian yang menarik untuk me-maparkan konsepsi pemikiran Ibnu sina tentang Pendidikan (Deswita, 2013: 169).

Berangkat dari permasalahan tersebut, maka dapat dirumuskan bagaimanan konsep filosofis pemikiran pendidikan yang dikembangkan oleh Ibnu Sina dan apa saja pokok-pokok pemikirannya yang dipandang masih aktual sebagai basis pemikiranya. Selain itu juga, penulis akan menganalisis epistemologi pemikiranya yang dimana memiliki berbagai konsep pemikiranya diantaranya, akar pemikiranya dan sumber pengetahuan yang dijadikan sebagai acuan dalam merumuskan pendidkan Islam sebagai salah satu jalan alternatif untuk mencapai sebuah tujuan dalam konteks kehidupan modern saat ini.

\section{Boigrafi Ibnu Sina}

Ibnu Sina merupakan tokoh pemikir muslim yang banyak menguasai bidang ilmu pengetahuan (baik itu ilmu-ilmu agama, sains, kedokteran dan Humaniora). Ibnu Sina nama lengkapnya adalah Ali al-Husien bin Abdullah al- Hasan bin Ali bin Sina. Ia dilahirkan di desa Afsyanah, dekat Bukhara, di kawasan Asia Tengah pada tahun $370 \mathrm{H}$ dan meninggal dunia di Hamadzan pada tahun 428 H (1038 M) dalam usia 57 tahun dan Negara-negara barat namanya lebih dikenal dengan sebutan Avicena.

Ia dilahirkan di Persia pada bulan Syafar 370 H/980 M. Namun orang Turki, Persia dan Arab mengklaim Ibnu Sina sebagai bangsanya. Hal ini dikarenakan ibunya berkebangsaan Turki, sedangkan ayahnya peranakan Arab. Ayahnya tinggal di kota Balkh, tetapi beberapa tahun setelah lahirnya Ibnu Sina, keluarganya pindah ke Bukhara karena ayahnya menjadi gubernur di suatu daerah di salah satu pemukiman Daulat Samaniyah pada masa pemerintahan Amir Nuh ibn Mansur (Putra, 2015: 193).

Ibnu Sina sejak usia muda sudah menguasai beberapa disiplin ilmu, seperti matematika, logika, fisika, kedokteran, astronomi, hukum, dan lain-lainnya, bahkan pada usia 10 tahun ia telah hafal Al- 
Qur'an seluruhnya. Ketika anak genius ini berusia 17 tahun, dengan kepintaran yang sangat mengagumkan, ia telah memahami seluruh ilmu kedokteran yang ada pada saat itu dan melebihi siapapun juga. Karena kepintarannya ini, ia diangkat menjadi konsultan dokterdokter praktisi. Peristiwa ini terjadi ketika ia berhasil mengobati Pangeran Nuh ibn Mashur, yang sebelumnya tidak seorang dokter pun mampu menyembuhkannya (Deswita, 2013: 170).

Pada usia 10 tahun ia telah menyelesaikan pelajaran al-Qur'an, sastra dan bahasa Arab. Kemudian ia belajar ilmu fiqh pada seorang guru bernama Ismail yang terkenal sebagai orang yang hidup zuhud. Di samping itu, ia belajar metematika dan ilmu ukur pada 'Ali Abu 'Abdullah an-Natili. Setelah itu ia belajar sendiri dengan membaca berbagai buku, termasuk buku Syarh sehingga menguasi ilmu semantik. Tidak ketinggalan pula ia mempelajari buku Ocledus mengenai ilmu ukur dan buku-buku tentang ilmu kedokteran. Dalam usia 18 tahun ia telah selesai mempelajari semua ilmu tersebut (Putra, 2015: 193).

Menjelang usia delapan belas tahun, ia telah menguasai logika, fisika, dan matematika, sehingga tidak ada lagi yang tersisa baginya kecuali metafisika. Setelah membaca metafisika Aristoteles sebanyak empat puluh kali, ia masih belum dapat memahami apa yang dimaksud pengarang. Sampai secara kebetulan ia menemukan sebuah salinan dari buku "Maksud-Maksud Metafisika Aristoteles", yang seketika itu juga memberi petunjuk padanya apa yang dimaksud Aristoteles (Baharuddin, 2015: 205-206).

\section{Karya-karya Ibnu Sina}

Sebelum masuk pembahasan terkait konsep pemikiranya, hal yang paling fundamental untuk diketahui adalah sebuah hasil karyakarya yang telah tersebar sekaligus berbagai konsep dasar. Dengan melihat karya tersebut. Penulis hendak akan melihat asumsi dasar pemikiranya terkait dengan pendidikian Islam. Adapaun Karya-karya Ibnu Sina sekitar sejumlah 276 tulisan dalam bentuk cetakan maupun manuskrip. Dari sekian banyak karya Ibnu Sina, tentu ada karya- 
karya yang dianggap populer yang membuat nama Ibnu Sina menjadi terkenal dalam kancah ilmu pengetahuan, terutama di dunia Barat.

Dalam hal ini, Ahmad Daudi mengatakan ada empat di antara karya Ibnu Sina yang terpenting, antara lain: asy-Syifa, al - Qanun fi alTibb, an-Najat dan al-Isyārat, Assiyasab (kitab tentang politik) yang isinya banyak membicarakan tentang pendidikan, seperti yang dipahami sekarang ini (Darwis, 2013: 245).

Pada usianya yang 22 tahun, ayahnya wafat. Ibnu Sina meninggalkan Bukhara menuju Jurjan, kemudian ke Khawarizm, akibat kekacauan politik ia berpindah dari suatu daerah ke daerah lainnya akhirnya sampai ke Hamazan. Oleh Syamsuddaulah, penguasa daerah ini, ia diangkat menjadi menteri beberapa kali, dan akhirnya ia pindah ke Isfahan dan mendapatkan sambutan yang istimewa dari penguasa daerah ini. Ibnu Sina wafat di Hamazan pada tahun 428 H./1037 M. dalam usia lima puluh delapan tahun (AlIrâqî, 1969:37), ia terserang penyakit dingin (cooling) yang tidak bisa disembuhkan lagi (Nur, 2009: 107 -108).

Dengan memahami bagaimana perjalanan hidup seorang Ibnu Sina, kita dapat menggetahui bahwa Ibnu Sina merupakan sosok yang multi talenta, mempunyai wawasan yang luas dan pemikiran yang cemerlang dari berbagai disiplin ilmu sebagaimana yang terlihat dalam karya-karyanya. Bukan hanya seorang filsuf namun juga seorang dokter, negarawan hingga tak heraan jika nama dan karyanya masih dikenal hingga saat ini. Kaitanya terhadap pendidikan yang menjadi bahan analisis pada sub pembahasan berikutnya.

\section{Konsep Pendidikan Islam dalam Perspektif Ibnu Sina}

Ibnu Sina adalah tokoh pemikir Muslim yang memadukan antara dimensi rasional dan religiusitas. Keduanya adalah hal yang saling mendukung dalam memecahkan persoalan dan realitas kehidupan. Fenomena kehidupan manusia dan fenomena alam merupakan realitas yang harus dimaknai dengan menggunakan sudut pandang yang beragam. Pendekatan tunggal dan sikap tidak menerima pendekatan baru akan menjadikan ilmu pengetahuan tidak akan kaya. Menurut Ibnu Sina ilmu terbagi menjadi dua, yaitu ilmu yang tak 
kekal dan ilmu yang kekal (hikmah). Ilmu yang kekal dipandang dari perannya sebagai alat dapat disebut logika (Putra, 2015: 194).

Objek kajian falsafah "hikmah", menurut Ibnu Sina terbagi menjadi dua bagian: Pertama, hikmah nadzariyah (ilmu teoritis) adalah bertujuan untuk membersihkan jiwa melalui ma'rifat. Yang termasuk ilmu ini adalah membahas masalah-masalah metafisika (ketuhanan), riyadhiyah (Matematika), dan thabiiyah (Fisika). Keduahikmah 'Amaliyah (Ilmu-Ilmu Praktis). Yang termasuk bagian dari ilmu-ilmu praktis adalah: Etika (Khuluqiyah), mengatur pergaulan keluarga dalam rumah tangga, ekonomi (Tadbir al-Manzil), mengatur pergaulan umat dalam Negara (Tadbir al-Madinab) dan kenabian (Gozali, :26).

Pandangan klasik tentang pendidikan, umumnya dikatakan sebagaia pranata yang mempunyai tiga tujuan. Pertama, menyiapkan generasi muda untuk memegang peranan-peranan tertentu dalam masyarakat di masa yang akan datang. Kedua, mentransfer pengetahuan sesuai dengan peranan yang diharapakan. Ketiga, mentransfer nilai-nilai dalam rangka memelihara keutuhan dan kesatuan masyarakat sebagai pra-syarat bagi kelangsungan hidup masyarakat dan peradaban manusia.

\section{Tujuan Pendiidkan Islam}

Menurut Ibnu Sina, tujuan pendidikan adalah untuk mencapai kebahagiaan (sa'adat), kebahagiaan dicapai secara bertingkat, sesuai dengan tingkat pendidikan yang dikemukakan-nya, yaitu kebahagiaan pribadi, rumah tangga, masyarakat, manusia secara menyeluruh dan kebahagiaan akhir yaitu akhirat. (Jalaluddin, 1994). Kebahagiaan yang menjadi tujuan dari pendidikan ini dapat diperoleh oleh setiap manusia dengan cara bertahap. Pada awalnya secara individu, yang akan tercapai bila individu memiliki kemuliaan akhlak. Bila individu sudah berakhlak, maka akan tercapai kebahagiaan rumah tangga. Kemudian jika masing-masing rumah tangga berpegang pada prinsip akhlak mulia, maka akan tercapai kebahagiaan dalam masyarakat, dan ini akan berimbas kepada kebahagiaan manusia secara menyeluruh. 
Tujuan pendidikan harus diarahkan kepada pengembangan seluruh potensi yang dimiliki seseorang ke arah perkembangannya yang sempurna, yaitu perkembangan intelektual, fisik, dan budi pekerti. Lebih lanjut, Ibnu Sina ber-pandangan bahwa tujuan pendidikan adalah untuk kemandirian dalam meng-emban beban hidup dan memberi manfaat kepada masyarakat dengan jalan membina tiap anggota masyarakat dengan pekerjaan mereka dengan baik. Apabila anak sudah cukup cakap dalam bidang kepandaianya, maka asuhan selanjutnya ialah memberi lapangan usaha baginya dan membimbing yang belajar hidup dari kepandaiannya itu.

Dengan demikian, terkait dengan tujuan pendidikan yang bersifat Islami, hendaknya dengan pendidikan jasmani atau olah raga anak diarahkan agar terbina per-tumbuhan fisiknya dan cerdas otaknya. Sedangkan dengan pendidikan budi pe-kerti, diharapkan anak-anak memiliki kebiasaan bersopan santun dalam per-gaulan hidup sehari-hari, dan dengan kesenian diharapkan dapat mempertajam perasaannya dan meningkatkan daya khayalnya (Deswita, 2013: 171 - 172).

Dalam hal ini, nampaknya Ibnu Sina mengarahkan bahwa tujuan pendidikan harus didasarkan pada pandangan tentang insan kamil (manusia yang paripurna) yakni manusia yang terbina seluruh potensi dirinya secara seimbang dan menyeluruh. Di sisi lain, ia juga mengatakan bahwa tujuan pendidikan itu juga diarahkan pada upaya persiapan seseorang agar dapat hidup dalam masyarakat secara bersama-sama dengan melakukan pekerjaan atau keahlian yang dipilihnya sesuai dengan bakat, kesiapan, kecenderungan dan potensi yang dimiliki.

Di sini beliau nampaknya dalam memformulasikan suatu tujuan melihat kepada perkembangan potensi dan bakat yang dimiliki oleh subjek didik secara optimal dan meyuluruh, sehingga subjek didik dapat mengembangkan dirinya agar tetap eksis dalam melaksanakan fungsinya yakni sebagai khalifatullah fi ardhi dalam masyarakat dengan suatu keahlian yang dapat diandalkan. Dengan tujuan seperti ini, Ibnu Sina tampaknya berusaha untuk melakukan antisipasi agar output yang dihasilkan oleh suatu lembaga pendidikan harus dapat siap 
kerja dengan keahlian yang dimilikinya, bukan subjek didik yang menjadi pengangguran. Jadi, tujuan yang diformulasikan oleh Ibnu Sina tersebut di samping menciptakan manusia yang paripurna (insan kamil) juga ingin mendapatkan kerja (vokasional). Dengan kata lain, Ibnu Sina dalam memformulasikan tujuan pendidikan melihat kepada dua tujuan yakni tujuan pendidikan yang sifat universal dan tujuan pendidikan yang bersifat vokasional (Darwis, 2013: 249 250).

Didalam sejarrah pendidikan, telah lahir banyak sekali para intelektual dan pemikir hebat, yang menarik dari seorang Ibnu sina yakni bahwa tujuan pendidikan Islam menurut bukan hanya mengembangkan pola kognitif saja, tapi mengembangkan afektif, psikokomor, dan spiritual seseorang, sehingga seluruh kemampuan dan potensi yang telah diberikan dapat dikembagkan. Dengan pendidikan manusia tidak hanya menjadi manusia yang berbudi pekerti yang baik tapi juga memiliki kemampuan intelektual yang membawa kebermanfaatan bagi diri dan lingkungannya. Memiliki akal yang cerdas, fisik yang sehat, dan akhlak yang mulia. Sehingga peran manusia sebagai seorang hamba, menjadi pemakmur bumi atau khalifatullah fil ardhi dapat berjalan sebagaimana yang mestinya dan bukan malah sebaliknya.

Selain tujuan mengembangkan seluruh potensi yang dimiliki, pendidikaan Islam juga harus mampu untuk mempersiapkan seseorang agar dapat hidup di masyarakat secara bersama-sama dengan melakukan pekerjaan atau keahlian yang dipilihnya sesuai dengan bakat dan potensi. Sehingga Ibnu sina juga menjelaskan bahwa objek kajian ilmu dibagi menjadi dua; petama yakni hikmah nadzariyah (ilmu teoritis) adalah bertujuan untuk membersihkan jiwa melalui ma'rifat. Kedua yakni hikmah 'Amaliyah (Ilmu-Ilmu Praktis). Ibnu Sina mencoba menyelaraskan tujuan pendidikan, baik tujuan jangka pendek atau tujuan duniawi, maupun tujuan jangka panjang yaitu tujuan ukhrawi. Setelah anak didik mengalami proses pendidikan, diharapkan ia mampu menghadapi kehidupannya seharihari sekaligus kelak diharapkan dia akan mendapatkan kebahagiaan di akhirat sesuai ajaran agama Islam. 


\section{Rekontruksi Fase-fase Pendidikan Perspektif Ibnu Sina}

Konsep pemikiran Ibnu Sina tentang pendidikan Islam selain menjelaskan tentang tujuan dan objek kajian ilmu yang telah di bahas pada paragraph sebelumnya, Ibnu Sina juga membahas tentang kurikulum tingkat pertama dalam pendidikan Islam. Ibnu Sina menulis karya tenntang pendididkan dan psikologi pendidikan dalam bukunya Risalah as Siyasah. Pandangan pemikiran Ibnu Sina tentang kurikulum tingkat pertama dikemukakan sebagai berikut;

1. Apabila anak berhenti menyusun (kira-kira pada fase pendidikan kanak-kanak) mulailah mendidik dan membina budi pekertinya, sebelum anak tersebut memperoleh sifat-sifat tercela dan tabiat yang buruk. Anak-anak cepat tertular tabiat yang buruk, bila sudah telanjur memiliki tabiat yang buruk akan lebih susah untuk dihilangkan (Fauzan, 2003: 125).

2. Pendidikan pertama yang diajarkan bagi anak sebaiknya adalah belajar Al-quran, tentu saja ketika anak tesebut telah siap secara fisik dan mental untuk belajar. Pada saat yang sama, anak seyogyanya juga belajar huruf abjad, diajarkan dasar-dasar agama, syair-syair yang mudah dihafal, kemudian syair yang Panjang (AlAAbrasyi, 1994: 13). Kandungan syair itu sebaiknya berisikan adab kesopanan, pujian terhadap ilmu pengetahuan, celaan kebodohan, serta dorongan berbuat kebaikan kepala orang tua, dan berbuat kebaijkan, menghormati tamu, dan lain sebagainya yang maksudnya pembinaan mental dan budi pekerti yang mulia (Fauzan, 2003: 125).

3. Bila anak sudah menyelesaikan pelajaan Al-Quran serta hafal kaidah-kaidah bahasa, mulailah memperhatikan minat atau keondongannya kepada keterampilan atau kepandaian dan bimbinglah kearah tersebut. Guru harus menyadari betul bahwa setiap pelajaran ketrampilan itu cocok bagi setiap anak, namun harus disesuaikan bakat dan minatnya. Jika anak senang dan minat pada ketrampilan tulis menulis, maka pelajaran tentang materi kepenulisan ditambahkan (Al-AAbrasyi, 1994: 15-16).

Kurikulum yang dikemukakan Ibnu Sina merupakan kurikulum dasar yang sebaiknya diajarkan kepada anak pada usia dasar sebagai 
sebuah pondasi untuk mempelajari ilmu-ilmu yang lebih luas lagi. Ibnu Sina memperhatikan prinsip-prinsip dalam pendidikan dengan memulai degan hal-hal yang sederhana, ringan, kemudian bealih kepada hal-hal sulit. Ibnu Sina membagi tingkatan materi ilmu pengetahuannyang harus dilalui anak didik harus berdasarkan tahap perkembangan dan usia pertumbuhan anak. Bemula dari pendidikan spiritual dengan mempekenalkan anak pada Al-Quran yang menjadi sumber pedoman umat Islam, membiasakan dan memahamkan tentang akhlak yang baik, dilanjutkan dengan mengarahkan pada bakat dan minat anak dengan mengajarkan materi-materi yang yang dapat membekali anak untuk hidup mandiri dapat memenuhi kebutuhan hidupnya di masa yang akan datang dengan ketampilan yang dimiliki (Mahrus, 2013: 80).

\section{Relevansi Konsep Pemikiran Pendidikan Islam Ibnu Sina Dengan Pendidikan Modern}

Era globalisasi saat ini identik dengan era sains dan teknologi yang pengembanganya tidak lepas dari studi kritis dan riset yang mendalam. Di satu sisi para saintis telah memerikan konstribusi untuk menejahterakan hidup umat manusia, namun di sisi lain manusia mulai kehilangan jati diri atau karakter dan pegangan hidup seperti nilai-nilai etika dan spiritual keagamaan, nilai-nilai luhur bangsa, nilai-nilai sosio-kultual atau tradisi budaya, dan nilai filsafat hidup. Sehingga nilai-nilai agama tepisah dari kehidupan. Agama hanya untuk akhirat, dan urusan dunia tidak berkaitan dengan agama. Dengan kemajuan iptek menjadikan manusia semakin jauh dengan agama. Bahkan membebaskan manusia dari serba Tuhan (Maragustam, 2018: 246)

Perkembangan ini mengakibatkan dinamisnya ilmu pengetahuan dan teknologi yang memberikan banyak dampak diantaranya revolusi industri, adalah ketika kemajuan teknologi yang besar disertai dengan perubahan sosial ekonomi dan budaya yang signifikan. Terminologi Revolusi Industri 4.0 pertama kali dikenal di Jerman pada 2011. Pada Industri 4.0 ditandai dengan integrasi yang kuat terjadi antara dunia digital dengan produksi industri. Revolusi 
industri 4.0 merupakan era digital ketika semua mesin terhubung melalui sistem internet atau cyber system. Situasi membawa dampak perubahan besar di masyarakat (Reflianto, 2018: 2)

Saat ini kita berada pada era revolusi industry 4.0 atau revolusi indutri ketiga. Tantangan pada dunia pendidikan dalam menghadapi industri 4 adalah penanaman nilai-nilai pendidikan yang perlu dikembangkan. Menurut Guilford (1985) penerapan dari pendidikan nilai yang dikembangkan adalah: 1) anak dididik dan dilatih dengan cara bekerja sambil belajar. Kecerdasan berfikir anak dikembangkan dengan seluas-luasnya; 2) memupuk kepribadian anak dengan kepribadian Indonesia sehingga menjadi pribadi yang dinamis, percaya diri, berani, bertanggung jawab dan mandiri; 3) pelajaran tidak hanya diberikan pada jam pelajaran saja, tetapi juga dalam setiap kesempatan di luar jam sekolah; dan 4) contoh perbuatan baik diterapkan karena lebih berhasil dalam membina watak yang baik. hal inilah yang membedakan manusia dengan mesin di era globalisasi industry ((Reflianto, 2018: 6).

Sayangnya, dengan adanya era revolusi indutri ini, pendidikan seolah hanya diarahkan pada aspek kognitif dan psikomotorik atau skill saja. Yang mana, dengan dikembangkanya aspek tersebut diharapkan peserta didik mampu mengussai skill yang diutuhkan, dan untuk memperoleh pekerjaan yang menjadi tuntutan pasar kerja dan dunia industri saat ini. Sehingga mengikis aspek afektif dan spiritual peserta didik.

Wacana tentang pengarahan peserta didik untuk lebih focus mempelajari bidang sains dan teknologi daripada social humaniora pun tak bias dihindarkan, karena memang kebutuhan industri saat ini pada sains dan teknologi. Jika peserta didik diajar hanya untuk "siap berkerja" pada industri maka secara tidak langsung pendidikan mematikan potensi peseta didik, yang mana seharusnya pendidikan menumuh kembangkan seluruh potensi yang dimiliki, baik secara kogniti, afektif, psikomotorik, dan sepiritual. Jika seluruh aspek ini ditumbuhkambangkan maka hal ini lah yang membedakan manusia dengan mesin. Tidak hanya bekeja tapi juga memberikan 
kesejahteraan dan kemanfaatan yang tidak hanya bisa dirasakan diri dan orang lain, bahkan lingkungan alam.

Meskipun zaman telah berganti, konsep pemikiran pendidikan yang dikemukan oleh Ibnu sina masih sangat relevan untuk diaplikasikan pada konsep pendidikan di era moden saat ini, yakni bahwa tujuan sebuah pendidikan adalah pengembangan seluruh potensi yang dimiliki seseorang ke arah perkembangan yang sempurna, yaitu perkembangan fisik, intelektual dan budi pekerti. Pendidikaan juga dimaksudkan untuk mendidik kemandirian dalam menyelesaikan problem yang dihadap pada zamannya, dan memberi kemanfaatan kepada masyarakat dengan membina tiap peserta didik dan masyarakat dengan baik. Sehingga manusia kembali pada perannya yakni menjadi seorang hamba dan khalifah di bumi, yang berujung pada kebahagiaan dunia akhirat.

Sejalan dengan konsep pendidikan Ibnu Sina, Prof. Maragustam juga menegaskan bahwa seorang khalifah dan hamba, manusia memiliki kodrat alamiahnya yang harus taat pada hukum-hukum Tuhan.konsekuensi etis dari hal ini ialah posisi kreatif manusia sebagai perwuudan khalifah selalu terjalin secara bersamaan dengan tuntutan kodratinya sebagai hamba yang tetap pada lingkup hokumhukum Tuhan. Posisi manusia sebagai khilafah harus dijalankan tanpa mengaaikan posisi manusia sebagai seorang hamba (Reflianto, 2018: 82).

\section{Catatan Akhir}

Ibnu Sina adalah tokoh pemikir Muslim yang memadukan antara dimensi rasional dan religiusitas. Keduanya adalah hal yang saling mendukung dalam memecahkan persoalan dan realitas kehidupan. Fenomena kehidupan manusia dan fenomena alam merupakan realitas yang harus dimaknai dengan menggunakan sudut pandang yang beragam. Pendekatan tunggal dan sikap tidak menerima pendekatan baru akan menjadikan ilmu pengetahuan tidak akan kaya.

Tujuan pendidikan harus diarahkan kepada pengembangan seluruh potensi yang dimiliki seseorang ke arah perkembangannya yang sempurna, yaitu perkembangan fisik, intelektual dan budi 
pekerti. Lebih lanjut, Ibnu Sina ber-pandangan bahwa tujuan pendidikan adalah untuk kemandirian dalam meng-emban beban hidup dan memberi ke-manfaatan kepada masyarakat dengan jalam membina tiap anggota masyarakat dengan pekerjaan mereka dengan baik. Apabila anak sudah cukup cakap dalam bidang kepandaianya, maka asuhan selanjutnya ialah memberi lapangan usaha baginya dan membimbing yang belajar hidup dari kepandaiannya itu.

Ibnu Sina membagi tingkatan materi ilmu pengetahuannyang harus dilalui anak didik harus berdasarkan tahap perkembangan dan usia pertumbuhan anak. Bemula dari pendidikan spiritual dengan mempekenalkan anak pada Al-Quran yang menjadi sumber pedoman umat Islam, membiasakan dan memahamkan tentang akhlak yang baik, dilanjutkan dengan mengarahkan pada bakat dan minat anak dengan mengajarkan materi-materi yang yang dapat membekali anak untuk hidup mandiri dapat memenuhi kebutuhan hidupnya di masa yang akan datang dengan kemampuan, dan ketrampilan berdasarkan potensi yang dimiliki.

\section{Daftar Pustaka}

Al-AAbrasyi, Muhammad Athiyah. 1994. Terjemah; Pokok-pokok pikiran Ibnu Sina tentang Pendidikan. Yogyakarta: Sumbansih Offset.

Anton, H Baker, Achmad Charis Zubair. 1990. Metode Penelitian Filsafat. Yogyakarta: Kanisius.

Baharuddin, Ahmad. 2015. Ibn Sina dan Pemikiran Teori Emanasi. Jurnal Adabiyah 15 (2).

Basri, Hasan. 2009. Filsafat Pendidikan Islam. Bandung: Pustaka Setia. Darwis, Maidar. 2013.Konsep Pendidikan Islam Dalam Perspektif Ibnu Sina. Jurnal Ilmiah Didaktika XIII (2).

Deswita. 2013. Konsep Pemikiran Ibnu Sina Tentang Pendidikan Akhlak. Jurnal Ta'dib 16 (2).

Farikhah, Siti. 2011. Manajemen Lembaga Pendidikan. Yogyakarta: Aswaja Pressindo.

Gozali, Mukhtar. Agama dan Filsafat Dalam Pemikiran Ibnu Sina. Jaqfi: Jurnal Aqidah dan Filsafat Islam 
Kartono, Kartini. 1996. Pengantar Metodologi Riset Sosial. Bandung: Mandur Maju.

Kurniadin, Didin. Imam Machali. 2012. Manajemen Pendidikan “Konsep \& Prinsip Pengelolaan Pendidikan”. Yogyakarta: Ar-Ruzz Media.

Kurniawan, Syamsul. 2013. Erwin Mahrus, Jejak Pemikiran Tokoh Pendidikan Islam. Yogyakarta: Ar-Ruzz Media.

Maragustam. 2018. Filsafat Pendidikan Islam menuju pembentukan karakter. Yogyakarta: Pascasarjana Fakulttas Tarbiyah dan Keguruan UIN Sunan Kalijaga.

Nur, Abdullah. 2009. Ibnu Sina: Pemikiran Fisafatnya Tentang AlFayd, Al-Nafs, Al-Nubuwwah, Dan Al-Wujûd. Jurnal Hunafa. $6(1)$.

Putra, Aris Try Andreas. 2015. Pemikiran Filosofis Pendidikan Ibnu Sina dan Impilikasinya pada Pendidikan Islam Kontemporer. Jurnal Literasi VI (2).

Suwito, Fauzan. 2003. Sejarah Pemikiran para Tokoh Pendidikan. Bandung: Penerbit Angkasa.

Syamsuar, Reflianto, 2018. Pendidikan Dan Tantangan Pembelajaran Berbasis Teknologi Informasi Di Era Revolusi Industri 4.0. E-Tech Jurnal Ilmiah Teknologi Pendidikan 6 (2). 